\title{
PENGARUH PEMBERIAN PUDING LIDAH BUAYA TERHADAP PENURUNAN KADAR KOLESTEROL TOTAL PENDERITA HIPERKOLESTEROLEMIA RAWAT JALAN PUSKEMAS GENUK KOTA SEMARANG
}

\author{
EFFECT OF ALOE VERA PUDDING ON DECREASING CHOLESTEROL LEVELS TOTAL HYPERCHOLESTEROLEMIC \\ PATIENTS OUTPATIENT IN GENUK PUSKEMAS SEMARANG CITY
}

\author{
Rizki Dyah Anggraeni ${ }^{1}$, Setyo Prihatin ${ }^{2}$, Ana Yuliah Rahmawati ${ }^{2}$
}

\begin{abstract}
Background : Hypercholesterolemia is a condition in which the total blood cholesterol level exceeds the normal value reaching $\geq 200 \mathrm{mg} / \mathrm{dl}$. To reduce total cholesterol levels can be done by regulating the intake of macro nutrients and micronutrients, one of which is fiber. Polysaccharide food fiber type hemicellulose which is glucomannan contained in aloe vera can reduce total cholesterol levels in the blood.
\end{abstract}

Objective : To know influence of giving aloe vera pudding on total cholesterol levels of Patients with Hypercholesterolemia Outpatient at Puskesmas Genuk Semarang City.

Method : This research used method quasi experimental with research design control group pre test post test. Taking sample on a random as many as 34 people for 2 groups that is treatment and control. The treatment group was given 100 grams of aloe vera for 14 days. Measurement of total cholesterol levels was carried out before and after the intervention. Fiber and fat intake subject before and during the intervention with 24-hour food recall method, while measurement activity physical use method IPAQ. Analysis statistics use Independent $t$ test, Paired t-test, and Anovarepeated measure.

Result : There were differences in changes in total cholesterol levels between groupstreatment and control were significant $(p=0.026)$ and there was a significant decrease in total cholesterol levels $(p=0.009)$ of $-44.70 \pm 56.51$ in the treatment group given aloe vera pudding.

Conclusion : Giving 100 grams of aloe vera pudding for 14 days could decrease total cholesterol levels of hypercholesterolemia patients of Puskesmas Genuk Semarang City.

Keywords : glucomannan, total cholesterol levels, aloe vera, aloe vera pudding

\section{ABSTRAK}

Latar belakang : Hiperkolesterolemia adalah suatu kondisi dimana kadar kolesterol total darah melebihi nilai normal mencapai $\geq 200 \mathrm{mg} / \mathrm{dl}$. Untuk menurunkan kadar kolesterol total dapat dilakukan dengan mengatur asupan gizi makro dan gizi mikro salah satunya adalah serat. Serat pangan polisakarida jenis hemiselulosa yaitu glukomanan yang terkandung dalam lidah buaya mampu menurunkan kadar kolesterol total dalam darah.

Tujuan : Mengetahui pengaruh pemberian puding lidah buaya terhadap kadar kolesterol total penderita hiperkolesterolemia rawat jalan Puskesmas Genuk Kota Semarang.

Metode : Penelitian ini menggunakan metode quasi experimental dengan desain penelitian control group pre test post test. Pengambilan sampel secara acak sebanyak 34 orang untuk 2 kelompok yaitu perlakuan dan kontrol. Kelompok perlakuan diberi puding lidah buaya sebanyak 100 gram selama 14 hari. Pengukuran kadar kolesterol total dilakukan sebelum dan setelah intervensi. Asupan serat dan lemak subjek sebelum dan selama intervensi menggunakan metode food recall 24 jam, sedangkan pengukuran aktivitas fisik menggunakan metode IPAQ. Analisis statistik menggunakan Independent t-test, Paired t-test, dan Anova repeated measure.

Hasil : Ada perbedaan perubahan kadar kolesterol total antara kelompok perlakuan dan kontrol $(p=0.026)$ dan ada penurunan kadar kolesterol total $(\mathrm{p}=0.009)$ sebesar $-44.70 \pm 56.51$ pada kelompok perlakuan yang diberi puding lidah buaya.

Kesimpulan : Pemberian 100 gram puding lidah buaya selama 14 hari dapat menurunkan kadar kolesterol total penderita hiperkolesterolemia rawat jalan Puskesmas Genuk Kota Semarang. 


\section{PENDAHULUAN}

Hiperkolesterolemia adalah suatu kondisi dimana kadar kolesterol total darah melebihi nilai normal $\geq 200 \mathrm{mg} / \mathrm{dl}^{1}$. Kadar kolesterol total yang tinggi akan membentuk aterosklerosis yang dapat menyebabkan hipertensi dan penyumbatan pembuluh darah otak, jantung dan pembuluh darah tungkai ${ }^{2}$. Penatalaksanaan penyakit hiperkolesterol dapat dilakukan dengan mengatur asupan gizi makro (karbohidrat, lemak, dan protein).Selain itu, upaya yang dapat menjadi alternatif lain dalam diet adalah dengan pengaturan asupan gizi mikro.

Adapun jenis zat gizi tersebut antara lain adalah vitamin B3, vitamin C, vitamin E, dan serat ${ }^{3}$. Salah satu upaya untuk menurunkan kadar kolesterol total dengan mengonsumsi bahan makanan alami seperti serat pangan (dietary fiber) ${ }^{4}$.Serat pangan adalah karbohidrat kompleks yang umumnya terdapat pada tumbuhan. Salah satu bahan makanan yang berpotensi menurunkan profil lipid adalah lidah buaya. Hasil penelitian Yulika Sianipar, menunjukkan bahwa jus aloe vera mampu menurunkan kadar kolesterol LDL sebesar 20,36\% dan meningkatkan kolesterol HDL sebesar $18,87 \%{ }^{5}$ sedangkan penelitian yang dilakukan oleh Evelin dan Susy pada tahun 2016 menunjukkan bahwa gel aloe vera efektif menurunkan kadar kolesterol total darah ${ }^{6}$. Lidah buaya memiliki penampilan yang berlendir, beraroma langu, dan rasanya getir ${ }^{4}$ untuk mengatasi hal tersebut perlu dilakukan adanya teknik pengolahan lidah buaya salah satunya adalah puding lidah buaya.

Tujuan penelitian ini untuk mengetahui pengaruh pemberian puding lidah buaya terhadap kadar kolesterol total pada penderita hiper kolesterolemia rawat jalan Puskesmas Genuk Kota Semarang.

\section{METODE}

Rancangan penelitian menggunakan quasi experimental pre post test control group design. Pengambilan sampel secara acak sebanyak 34 orang dengan masing-masing 17 orang pada kelompok perlakuan maupun kelompok kontrol. Kelompok perlakuan dalam penelitian ini diberi puding lidah buaya dengan dosis 1 x 100 gram selama 14 hari.yang diberikan 1 kali perhari pada waktu sore hari yang dikonsumsi sebagai snack, sedangkan kelompok kontrol tidak diberi puding lidah buaya.

Penelitian dilakukan di wilayah kerja Puskesmas Genuk Kota Semarang yang terdiri dari 34 orang dan dilakukan selama 14 hari (23 April - 6
Mei 2018). Subjek dalam penelitian ini adalah penderita hiperkolesterolemia yang memiliki kadar kolesterol total $\geq 200 \mathrm{mg} / \mathrm{dl}$, berusia 40-65 tahun, tidak memiliki riwayat penyakit Diabetes Mellitus, tidak mengonsumsi obat antihiperkolesterolemia atau minuman dan suplemen yang dapat menurunkan kolesterol total, bersedia menjadi responden secara tertulis, dan bertempat tinggal di wilayah kerja Puskesmas Genuk Kota Semarang. Instrumen yang digunakan terdiri dari formulir identitas subjek penelitian, formulir informed concernt, formulir pengecekan kadar kolesterol total, dan formulir recall $3 \times 24$ jam. Penentuan status gizi dari hasil pengukuran berat badan yang diukur menggunakan timbangan digital dan tinggi badan yang diukur menggunakan microtoice. Kadar kolesterol total subjek sebagai variabel dependent yang diukur pada sebelum dan setelah intervensi menggunakan GCU (Glucose, Cholesterol, Uric Acid) merkAutocheck. Pemberian puding lidah buaya sebagai variabel independent diperoleh dengan menggunakan formulir checklist asupan puding. ASupan serat, asupan lemak, dan aktivitas fisik sebagai variabel confounding diperoleh dengan metode food recall $3 \times 24$ jam dengan waktu yang tidak berurutan. Data aktivitas fisik diperoleh dengan metode International Physical Activity Quationnaire (IPAQ).

Hasil analisis kadar kolesterol total sebelum dan setelah intervensi antara kelompok perlakuan dan kontrol dan perbedaan asupan serat dan lemak pada kelompok perlakuan dan kelompok kontrol menggunakan uji Independent T-Test. Sedangkan untuk mengetahui pengaruh pemberian puding lidah buaya yang dikontrol dengan asupan serat, asupan lemak, dan aktivitas fisik terhadap perubahan kadar kolesterol total menggunakan uji Anova Repeated Measure.

\section{HASIL PENELITIAN}

Penelitian ini dilakukan pada penderita hiperkolesterolemia rawat jalan Puskesmas Genuk Kota Semarang sebanyak 34 orang selama 14 hari (23 April - 6 Mei). Jumlah subjek penelitian sebanyak 34 orang, dengan rincian masing-masing 17 orang di tiap kelompok.

\section{KarakteristikSubjekPenelitian}

Tabel 1. Karakteristik Subjek Penelitian 


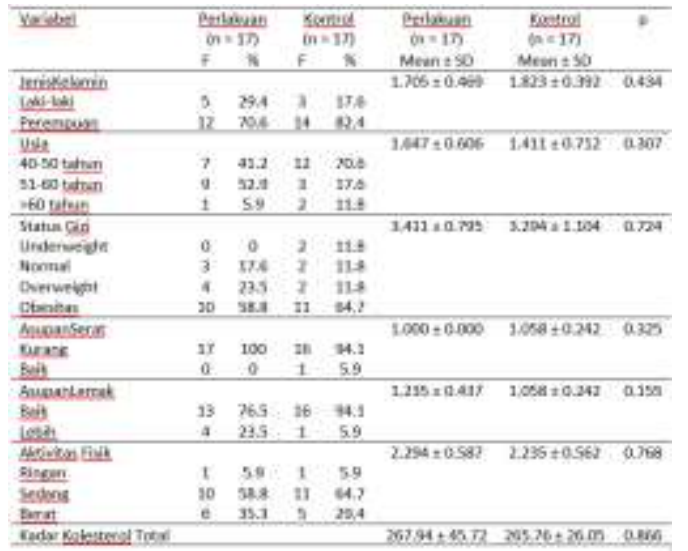

Keterangan : $\mathrm{p}=$ Independent $\mathrm{t}$-test

Subjek penelitian berjumlah 34 orang. Subjek merupakan penderita hiperkolesterolemia rawat jalan Puskesmas Genuk Kota Semarang. Terdapat beberapa faktor yang memengaruhi kadar kolesterol total yaitu usia, jenis kelamin, obesitas, pola makan tinggi serat, pola makan tinggi lemak, dan aktifitas fisik ${ }^{9}$. Berdasarkan hasil data statistik pada penelitian tidak terdapat perbedaan karakteristik usia, jenis kelamin, status gizi, asupan serat, asupan lemak, aktivitas fisik, dan kadar kolesterol total antara kelompok perlakuan dan kelompok kontrol sebelum intervensi yang menunjukkan bahwa subjek penelitian adalah homogen. Sebagian besar subjek berjenis kelamin perempuan, sebanyak $70.6 \%$ pada kelompok perlakuan dan sebanyak $82.4 \%$ pada kelompok kontrol dengan rentan usia subjek berkisar 52,9\% usia 51 - 60 tahun pada kelompok perlakuan dan $70.6 \%$ usia $40-50$ tahun pada kelompok kontrol. Hal ini menunjukkan bahwa usia dan jenis kelamin berpengaruh terhadap peningkatan kadar kolesterol total. Perempuan merupakan kelompok yang paling banyak dijumpai menderita penyakit metabolisme lemak dibandingkan laki-laki ${ }^{10}$, hal ini terjadi pada wanita yang memasuki masa menopouse, kadar kolesterol dalam darah cenderung meningkat hal ini dikarenakan hormon estrogen sudah tidak terbentuk dan lebih berisiko mengalami penyakit jantung. Beberapa studi menyimpulkan bahwa setelah menopause diperkirakan 5-19\% wanita mengalami peningkatan kadar kolesterol $^{1}$. Hiperkolesterolemia pada umumnya terjadi pada usia dewasa. Diketahui bahwa usia yang berisiko lebih besar menderita hiperkolesterolemia adalah lebih dari 45 tahun, semakin berumur seseorang, maka makin berkurang kemampuan reseptor LDL-nya. Sedangkan reseptor LDL merupakan faktor penghambat (inhibitor) sintesis kolesterol dalam tubuh sehingga menurunnya aktivitas reseptor LDL akibat semakin bertambah usia akan menyebabkan sintesis kolesterol menjadi meningkat sehingga kadar total kolesterol tinggi ${ }^{11}$.

Berdasarkan status gizi, sebagian besar subjek penelitian berstatus gizi obesitas dengan IMT $\geq 25 \mathrm{~kg} / \mathrm{m}^{2}$. Sebanyak $58.8 \%$ subjek obesitas pada kelompok perlakuan sedangkan sebanyak $64.7 \%$ subjek obesitas pada kelompok kontrol. Diketahui bahwa setiap peningkatan $1 \mathrm{~kg} / \mathrm{m}^{2}$ IMT berhubungan dengan kolesterol total plasma $7,7 \mathrm{mg} / \mathrm{dl}$ dan penurunan $\mathrm{HDL} 0,8 \mathrm{mg} / \mathrm{dl}$. Pada orang obesitas menghasilkan peningkatan angka sintesis kolesterol endogen yaitu $20 \mathrm{mg}$ setiap hari untuk setiap kilogram kelebihan berat badan, peningkatan VLDL dan angka produksi trigliserida ${ }^{12}$

Asupan serat subjek penelitian sebanyak $100 \%$ pada kelompok perlakuan memiliki asupan serat $<20$ gram per hari sedangkan asupan serat pada kelompok kontrol sebanyak $94.1 \%$ memiliki asupan sarat < 20 gram per hari. Seseorang yang kurang mengkonsumsi serat mempunyai risiko tinggi menderita hiperkolesterol ${ }^{9}$. Hal ini sesuai dengan penelitian Shreya (2014) bahwa ada hubungan antara asupan serat makanan dengan kadar kolesterol total dan LDL. Seseorang yang kurang mengkonsumsi serat ( $<29 \mathrm{~g} /$ hari) mempunyai risiko sebesar $38 \%$ dan $43 \%$ lebih tinggi untuk mengalami hiperkolesterolemia dan mempunyai kadar LDL yang tinggi dibanding dengan yang mengkonsumsi serat $>29$ g/hari ${ }^{9}$. Sedangkan asupan lemak pada subjek penelitian sebanyak $76.5 \%$ asupan lemak kategori baik karena asupan lemak $15-30 \%$ dari total kebutuhan per hari pada kelompok perlakuan dan sebanyak $94.1 \%$ asupan lemak kategori baik pada kelompok kontrol. Asupan tinggi lemak jenuh, asam lemak trans, dan kolesterol dapat menyebabkan peningkatan kolesterol total. Lemak jenuh meningkatkan kadar kolesterol dengan menurunkan sintesis dan aktivitas reseptor kolesterol ${ }^{13}$. Hati akan mempunyai cukup kadar kolesterol dan akan menghentikan pengambilan LDL yang dapat meningkatkan kadar kolesterol total ${ }^{9}$.

Aktivitas fisik subjek penelitian sebagian besar dalam kategori sedang (>600 METs-min/minggu). Pengukuran aktivitas fisik dilakukan dengan mengukur banyaknya energi yang dikeluarkan atau dibutuhkan pada setiap menit kegiatan menggunakan metode IPAQ ${ }^{14}$. Aktivitas fisik meliputi aktivitas sehari-hari, kebiasaan, hobi, maupun latihan jasmani dan 
olahraga. Olahraga yang teratur dapat menyebabkan kadar kolesterol total, kolesterol LDL dan trigliserida menurun dalam darah sedangkan kolesterol HDL meningkat ${ }^{15}$. Aktivitas fisik yang rendah dapat mempengaruhi kadar kolesterol total. Perubahan aktivitas fisik dan berkurangnya frekuensi olahraga memungkinkan kolesterol yang ada tidak dapat mengalami proses metabolisme dan pembakaran yang sempurna, dalam hal ini kolesterol yang ada makin menumpuk dalam pembuluh darah ${ }^{16}$.

Kadar kolesterol total subjek sebelum intervensi sesuai dengan kriteria memiliki kadar kolesterol total $\geq 200 \mathrm{mg} / \mathrm{dL}$. Menurut National Institute of Health (NIH)-USA kadar kolesterol total darah sedang atau ambang batas tinggi (borderline high) adalah 200-239 mg/dli7, seseorang dikatakan hiperkolesterolemia apabila memiliki kadar kolesterol $\geq 200 \mathrm{mg} / \mathrm{dL}^{18}$. Berdasarkan hasil uji statistik tidak ditemukan adanya perbedaan kadar kolesterol total yang signifikan antara kelompok perlakuan dengan kelompok kontrol sebelum intervensi $(p=$ $0.866)$, rata-rata kadar kolesterol total pada kelompok perlakuan sebesar $267.94 \mathrm{mg} / \mathrm{dL}$ sedangkan kelompok kontrol sebesar $265.76 \mathrm{mg} / \mathrm{dL}$.

2. Perbedaan Kadar Kolesterol Total SebelumdanSetelahIntervensiantaraKelompok PerlakuandanKelompokKontrol

Tabel 2. Perbedaan kadar kolesterol total sebelum dan setelah intervensi

\begin{tabular}{|c|c|c|c|c|}
\hline \multirow{2}{*}{ Variabed } & \multirow{2}{*}{\multicolumn{4}{|c|}{ Kodremoui }} \\
\hline & Eechotuan & & Rostrol & 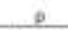 \\
\hline Koiesterses totai setselum & $267.94 \times 55.72$ & $2002^{2}$ & $265.76+26.05$ & $0.236 \%$ \\
\hline 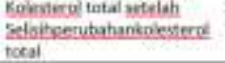 & $\begin{array}{l}226.76+26.05 \\
44.70+5651\end{array}$ & & $\begin{array}{l}255.94+35.44 \\
7.96+33.49\end{array}$ & $0,026^{\circ}$ \\
\hline
\end{tabular}

Kerangan : $\mathrm{p}^{*}=$ signifikan, $\mathrm{a}=$ uji paired $t$-test, $\mathrm{b}=\mathrm{uji}$ independent $t$-test

Kelompok perlakuan mengalami penurunan kadar kolesterol total yang bermakna $(p=0.009)$ setelah pemberian puding lidah buaya selama 14 hari yaitu sebesar -44.70 $\mathrm{mg} / \mathrm{dl}$. Rata-rata kadar kolesterol total kelompok perlakuan sebelum intervensi sebesar $267.94 \mathrm{mg} / \mathrm{dl}$ dan setelah intervensi sebesar $226.17 \mathrm{mg} / \mathrm{dl}$. Kelompok kontrol juga mengalami penurunan kadar kolesterol total sebesar $-7.58 \mathrm{mg} / \mathrm{dl}$. Namun, penurunan kadar kolesterol total pada kelompok kontrol tidak bermakna $(p=0.236)$. Rata-rata kadar kolesterol total sebelum intervensi pada kelompok kontrol sebesar $265.76 \mathrm{mg} / \mathrm{dl}$ dan setelah intervensi tanpa pemberian puding lidah buaya sebesar $255.94 \mathrm{mg} / \mathrm{dl}$.

Berdasarkan hasil uji independent $t$ test, terdapat perbedaan perubahan kadar kolesterol total ( $\Delta$ Kolesterol total) yang bermakna antara kelompok perlakuan dengan kelompok kontrol $(p=0.026)$ dengan rata-rata penurunan sebesar $-44.70 \pm 56.51 \mathrm{mg} / \mathrm{dl}$ pada kelompok perlakuan dan sebesar -7.58 \pm $33.49 \mathrm{mg} / \mathrm{dl}$ pada kelompok kontrol. Hal ini menunjukkan ada pengaruh pemberian puding lidah buaya sebanyak 100 gram dengan kandungan glukomanan sebesar $0.801 \%$ selama 14 hari terhadap penurunan kadar kolesterol total kelompok perlakuan dibandingkan dengan kelompok kontrol yang tidak diberikan puding lidah buaya. Peran puding lidah buaya dalam menurunkan kadar kolesterol total diketahui berasal dari kandungan glukomanan pada lidah buaya. Berdasarkan hasil uji laboratorium, kandungan glukomanan pada puding lidah buaya sebesar $0.801 \%$ dalam 100 gram puding lidah buaya.

\section{KecukupanAsupanSeratdanLemakSelamaInter} vensi

Tabel 3. Kecukupan asupan serat dan lemak selama intervensi

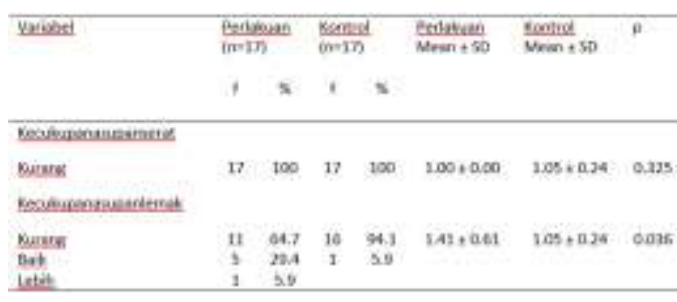

Keterangan $: \mathrm{p}=$ Independent $t$-test

Tidak terdapat perbedaan yang bermakna pada kecukupan asupan serat antara kelompok perlakuan dan kontrol selama intervensi ( $p>0.05$ ) dan ada perbedaan kecukupan asupan lemak antara kelompok perlakuan dan kontrol selama intervensi ( $p<$ 0.05). Kecukupan asupan serat pada kelompok perlakuan maupun kontrol dalam kategori kurang yaitu sebanyak $100 \%$ asupan serat subjek kurang (<80\% AKG). Kecukupan asupan lemak pada kelompok kontrol dalam kategori kurang lebih tinggi dibandingkan kelompok perlakuan yaitu sebanyak 94.1\%, sedangkan kecukupan asupan lemak kategori baik pada kelompok perlakuan lebih tinggi dibandingkan kelompok kontrol yaitu $29.4 \%$.

Kecukupan asupan serat subjek penelitian dalam kategori kurang (<80\% AKG) 
sebanyak $100 \%$. Rata-rata asupan serat pada kelompok perlakuan hanya 4.59 gram sedangkan kelompok kontrol hanya 5.25 gram. Hal ini dikarenakan subjek kurang mengonsumsi bahan makanan yang mengandung serat.Serat pangan terbagi menjadi dua kelompok,yaitu serat pangan larut (soluble dietary fiber) dan serat tidak larut (insoluble dietary fiber). Pektin dan gum merupakan bagian dalam dari sel pangan nabati yang merupakan serat pangan larut. Serat ini banyak terdapat pada buah dan sayur. Sedangkan selulosa, hemiselulosa dan lignin, yang banyak ditemukan pada seralia, kacang-kacangan dan sayuran merupakan serat tidak larut ${ }^{19}$. Berdasarkan hasil food recall menunjukkan bahwa konsumsi sayur, buah, mapun kacang-kacangan pada subjek penelitian kurang sehingga asupan serat tidak mencukupi kebutuhan.

Kebiasaan makan subjek mengonsumsi makanan yang berlemak seperti gorengan, santan, dan jeroan. Namun, berdasarkan hasil uji statistik kecukupan asupan lemak subjek penelitian masih dalam kategori kurang sebanyak $64.7 \%$ pada kelompok perlakuan dan 94.1\% pada kelompok kontrol. Hal ini yang menyebabkan adanya perbedaan yang signifikan kecukupan asupan lemak pada kelompok perlakuan dengan kelompok kontrol. Kategori kecukupan asupan lemak pada kelompok perlakuan lebih bervariasi yaitu kurang (<80\% AKG) sebanyak $64.7 \%$, baik (80$110 \%$ AKG) sebanyak $29.4 \%$ dan lebih (>110\% AKG) sebanyak $5.9 \%$ sedangkan kategori kecukupan asupan lemak pada kelompok kontrol selama intervensi yaitu kurang ( $<80 \%$ AKG) sebanyak $94.1 \%$ dan baik (80-110\% AKG) sebanyak $5.9 \%$.

4. PengaruhPemberianPudingLidahBuayaTerhad apPenurunan Kadar Kolesterol Total

Tabel 4. Pengaruh pemberian puding lidah buaya terhadap perubahan kadar kolesterol total yang dikontrol dengan asupan serat, asupan lemak, dan aktivitas fisik

\begin{tabular}{llll}
\hline Variabel & Mean Square & $F$ & Sig \\
\hline Asupanserat & 29.227 & 0.018 & 0.893 \\
Asupanlemak & 6346.768 & 4.009 & 0.055 \\
Aktivitasfisik & 5843.829 & 3.691 & 0.065 \\
Kelompok & 6867.320 & 4.338 & 0.046 \\
\hline
\end{tabular}

Keterangan : $\mathrm{p}=$ Anova Repeated Measur

Berdasarkan grafik penurunan kadar kolesterol total bahwa kolesterol total kelompok perlakuan maupun kelompok kontrol mengalami penurunan. Faktor 1 adalah kolesterol total sebelum intervensi sebesar $267.94 \mathrm{mg} / \mathrm{dl}$ dan faktor 2 adalah kadar kolesterol total setelah intervensi yaitu sebesar $226.17 \mathrm{mg} / \mathrm{dl}$. Sedangkan kadar kolesterol total kelompok kontrol sebelum intervensi sebesar $265.76 \mathrm{mg} / \mathrm{dl}$ dan setelah intervensi sebesar $255.94 \mathrm{mg} / \mathrm{dl}$. Berdasarkan hasil statistik uji Anova Repeated Measure menunjukkan bahwa ada pengaruh pemberian puding lidah buaya terhadap penurunan kadar kolesterol total yang dikontroldengan asupan serat, asupan lemak, dan aktivitas fisik.

Hal ini terjadi karena asupan serat dan asupan lemak tidak ada perbedaan pada kelompok perlakuan maupun kelompok kontrol. Setelah pemberian puding lidah buaya pada kelompok perlakuan yang rata-rata asupan serat 4.70 gram belum sesuai dengan Angka Kecukupan Gizi yaitu 20-30 gram. Diketahui bahwa asupan serat dapat menurunkan kolesterol dengan cara meningkatkan pengeluaran cairan empedu dengan cara serat mengikat garam empedu sehingga menurunkan kadar kolesterol dan bakteri di dalam kolon memfermentasikan serat untuk mempoduksi asetat, propionat, butirat untuk menghambat sintesis kolesterol, menghambat absorbsi kolesterol, menurunkan ketersediaan kolesterol sehingga transfer ke aliran darah berkurang, kemudian cairan empedu untuk disekresikan bersama feses ${ }^{8}$. Selain asupan serat yang dapat mempengaruhi kadar kolesterol adalah asupan lemak. Rata-rata asupan lemak 42.45 gram atau kecukupan asupan lemak $<80 \%$ AKG dan tidak ada perubahan bermakna asupan lemak sebelum dan selama intervensi pada kelompok perlakuan maupun kelompok kontrol. Sehingga, penurunan kadar kolesterol total terjadi karena pemberian puding lidah buaya.

Penurunan signifikan kadar kolesterol total pada kelompok perlakuan ( $p=0.026$ ) karena pemberian puding lidah buaya sebanyak 100 gram selama 14 hari. Hal ini sesuai dengan penelitian yang pernah dilakukan bahwa jus lidah buaya $200 \mathrm{~g} /$ hari selama 14 hari mampu menurunkan kadar kolesterol LDL sebesar 20,36\% dan meningkatkan kolesterol HDL sebesar $18,87 \%$ pada wanita dislipidemia ${ }^{5}$. Selain itu, penelitian lain menunjukkan bahwa terapi 7 hari dengan gel aloe vera baik dosis 100 gram maupun dosis 200 gram efektif menurunkan kadar total kolesterol darah pada orang dewasa usia 30-60 tahun ${ }^{6}$.

Peran lidah buaya dalam menurunkan kadar kolesterol total diketahui berasal dari 
polisakarida yang terdapat didalam lidah buaya yaitu glukomanan. Glukomanan adalah polisakarida dari dietary fiber jenis hemiselulosa yang terdiri dari rantai glukosa, mannose, dan galaktosa ${ }^{18}$. Glukomanan memiliki sifat sebagai serat yang mampu menyerap air. Peran glukomanan menurunkan kolesterol total dengan cara mengikat garam empedu di lumen usus. Secara normal lebih dari 95\% garam empedu akan di daur ulang dengan cara diserap oleh darah dan dikembalikan lagi di hati. Serat ini akan menghambat proses daur ulang dan garam empedu akan disekresikan melalui feses, sehingga hanya sedikit garam empedu yang dikembalikan ke hati. Hal ini akan merangsang hati untuk membentuk garam empedu yang baru dan akan mengambil kolesterol dari darah sebagai bahan pembentuk garam empedu. Semakin banyak garam empedu yang dibentuk maka kolesterol yang beredar di dalam darah akan semakin berkurang atau turun ${ }^{19}$.Diketahui bahwa puding lidah buaya mengandung glukomanan sebesar $0.801 \%$ sehingga dapat menurunkan kadar kolesterol pada kelompok perlakuan. Hasil penelitian ini sejalan dengan penelitian yang telah dilakukan tentang pengaruh glukomanan pada lidah buaya. Penelitian yang dilakukan Nasim Dana et al. terhadap kelinci hiperkolesterolemia yang diberikan gel dari daun lidah buaya terhadap 32 kelinci jantan selama 30 hari menunjukkan bahwa total kolesterol dan CRP (C-reactive protein) mengalami penurunan level yang signifikan pada kelompok yang menerima diet kolesterol dengan lidah buaya ${ }^{20}$ dan penelitian yang dilakukan Martino, et al menyatakan bahwa glukomanan pada gel lidah buaya yang diberikan pada salah satu kelompok anak anak dapat menurunkan nilai total kolesterol ${ }^{21}$.

\section{KESIMPULAN}

Pemberian puding lidah buaya dengan dosis 1 x 100 gram sehari dengan kandungan glukomanan sebesar $0.801 \%$ dapat menurunkan kadar kolesterol total pada subjek penelitian dengan rerata penurunan sebesar $44.70 \mathrm{mg} / \mathrm{dL}$.

\section{SARAN}

Dianjurkan untuk mengkonsumsi puding lidah buaya dengan dosis 1 x 100 gram untuk menurunkan kadar kolesterol total dalam darah.

\section{DAFTAR PUSTAKA}

1. Ayuandira A. Hubungan Pola Konsumsi Makan , Status Gizi , Hiperkolesterolemia Pada Karyawan Pt Semen Padang Tahun 2012 Hiperkolesterolemia Pada Karyawan Pt Semen Padang Tahun 2012. 2012;

2. Putri Va, Hariyono, Sari Ep. Gambaran Kadar Kolesterol Total Pada Lansia. J Insa Cendikia. 2016;4(1):34-9.

3. Muzakar, Dinarti K, Asturi H. Upaya Asupan Serat.Pdf. J Gizi Klin Indones. 2010;6.

4. Hartanto Es, Lubis Eh. Pengolahan Minuman Sari Lidah Buaya (Aloevera Linn). Bogor: Balai Besar Penelitian Dan Pengembangan Industri Hasil Pertanian; 2002. P. 29-35.

5. Sianipar Y, Isnawati M. Terhadap Kadar Kolesterol Low Density Lipoprotein ( Ldl ) Dan High Density Lipoprotein ( Hdl ). J Nutr Clolege. 2012;1(Ldl).

6. Malinti E, Jael Sa. Menurunkan Kadar Kolesterol Darah Dengan Gel Aloe Vera Linn. Sk Keperawatan. 2016;2(2):159-64.

7. Wirya Lpai. Pemberian Ekstrak Air Lidah Buaya (Aloe Vera L.) Memperbaiki Profil Lipid Darah Tikus Jantan Wistar Dengan Dislipidemia. Universitas Udayana Denpasar; 2012.

8. Setyaningtyas A. Pengaruh Suplementasi Agar-Agar Terhdap Kadar Kolesterol Total, Kolesterol Ldl, Kolesterol Hdl Dan Trigliserol Pada Serum Tikus Dengan Tinggi Lemak. Universitas Airlangga Surabaya; 2003.

9. Yoeantafara A, Martini $S$, Fakultas $M$, Masyarakat K, Airlangga U, Epidemiologi D, Et Al. Pengaruh Pola Makan Terhadap Kadar Kolesterol. :304-9.

10. Grundy Sm, Cleeman Ji, Merz Cnb, Brewer $\mathrm{Hb}$, Clark Lt, Hunninghake Db, Et Al. Ncep Report National Cholesterol Education Program. J Am Coll Cardiol [Internet]. 2004;44(3):720-32. Available From: Http://Dx.Doi.Org/10.1016/J.Jacc.2004.07.00 1

11. Ayuandira A. Hubungan Pola Konsumsi Makan , Status Gizi , Hiperkolesterolemia Pada Karyawan Pt Semen Padang Tahun 2012 Hiperkolesterolemia Pada Karyawan Pt Semen Padang Tahun 2012. 2012;

12. Putri Va, Hariyono, Sari Ep. Gambaran Kadar Kolesterol Total Pada Lansia. J Insa Cendikia. 2016;4(1):34-9.

13. Muzakar, Dinarti K, Asturi H. Upaya Asupan Serat.Pdf. J Gizi Klin Indones. 2010;6.

14. Hartanto Es, Lubis Eh. Pengolahan Minuman Sari Lidah Buaya (Aloevera Linn). Bogor: Balai Besar Penelitian Dan Pengembangan Industri Hasil Pertanian; 2002. P. 29-35. 
15. Sianipar $\mathrm{Y}$, Isnawati M. Terhadap Kadar Kolesterol Low Density Lipoprotein ( Ldl ) Dan High Density Lipoprotein ( Hdl ). J Nutr Clolege. 2012;1(Ldl).

16. Malinti E, Jael Sa. Menurunkan Kadar Kolesterol Darah Dengan Gel Aloe Vera Linn. Sk Keperawatan. 2016;2(2):159-64.

17. Wirya Lpai. Pemberian Ekstrak Air Lidah Buaya (Aloe Vera L.) Memperbaiki Profil Lipid Darah Tikus Jantan Wistar Dengan Dislipidemia. Universitas Udayana Denpasar; 2012.

18. Setyaningtyas A. Pengaruh Suplementasi Agar-Agar Terhdap Kadar Kolesterol Total, Kolesterol Ldl, Kolesterol Hdl Dan Trigliserol Pada Serum Tikus Dengan Tinggi Lemak. Universitas Airlangga Surabaya; 2003.

19. Yoeantafara A, Martini S, Fakultas $M$, Masyarakat K, Airlangga U, Epidemiologi D, Et Al. Pengaruh Pola Makan Terhadap Kadar Kolesterol. :304-9.

20. Grundy Sm, Cleeman Ji, Merz Cnb, Brewer Hb, Clark Lt, Hunninghake Db, Et Al. Ncep Report National Cholesterol Education Program. J Am Coll Cardiol [Internet]. 2004;44(3):720-32. Available

From: Http://Dx.Doi.Org/10.1016/J.Jacc.2004.07.00 1

21. Matondang Hf. Pengaruh Pemberian Sari Belimbing Wuluh. 2016.

22. Setiono Ly. Dislipidemia Pada Obesitas Dan Tidak Obesitas. 2012.

23. Lawrence Gd. Dietary Fats And Health: Dietary Recommendations In The Context Of Scienti Fi C Evidence 1. 2018;(June).

24. Fisik A, Pola Dan, Dengan M, Sentral O. Pada Tokoh Agama Di Kota Manado. 2012;4(1):289-98.

25. Leon As, Sanchez Oa. Alone Or Combined With Dietary Intervention. (52).

26. Rahma Musdalifa N, Wicaksono S, Studi Pendidikan Dokter Fakultas Kedokteran Universitas Halu Oleo P, Histologi Fakultas Kedokteran Universitas Halu Oleo B. Hubungan Indeks Massa Tubuh Dengan Kadar Kolesterol Total Pada Staf Dan Guru Sma Negeri 1 Kendari. 2017;4(2):361-7.

27. Soeharto I. Kolesterol \& Lemak Jahat, Kolesterol \& Lemak Baik Dan Proses Terjadinya. Kedua. Jakarta: Pt Gramedia Pustaka Utama Jakarta; 2002.

28. Maulida M, Mayasari D, Rahmayani F. Pengaruh Rasio Kolesterol Total Terhadap High Density Lipoprotein ( Hdl ) Pada Kejadian Stroke Iskemik The Influence of Total Cholesterol Ratio Against High Density Lipoprotein ( $\mathrm{Hdl}$ ) In The Incidence Of Ischemic Stroke. 2018;7(21):214-8.
29. Pangan S, Fiber D, Manfaatnya Dan. Serat Pangan. 2011;(75):35-40.

30. Penelitian Ah, Dewi M, Aminah M. Indonesian Journal Of Human Nutrition. 2016;3(1):1-8.

31. Kartoni $\mathrm{H}$, Haryanto J, Fauziningtyas R. Jurnal Kebidanan Menurunkan Kadar Kolesterol Total Darah Pada Lansia Hiperkolesterolemia Atau Dewasa Penderita Dislipidemia Berperan Penting Dalam Terjadinya Aterosklerosis Yang Merupakan Suatu Proses Degeneratif Dan Pada Lanjut Usia Pada Kelompok Umur La. 2017;|x(1):1-14.

32. Nugraheni B, Cahyani Im, Herlyanti K. Efek Pemberian Glukomanan Umbi Porang ( Amorphophallus Oncophyllus Prain Ex Hook . F . ) Terhadap Kadar Kolesterol. :32-6.

33. Dana N, Javanmard Sh, Asgary S, Asnaashari H, Abdian N. The Effect Of Aloe Vera Leaf Gel On Fatty Streak Formation In Hypercholesterolemic Rabbits. J Res Med Sci. 2012;17(5):439-42.

34. Martino F, Martino E, Morrone F, Carnevali E, Forcone R, Niglio T. Effect Of Dietary Supplementation With Glucomannan On Plasma Total Cholesterol And Low Density Lipoprotein Cholesterol In Hypercholesterolemic Children. 2005;15(3):174-180. 